\section{Management Practices of Growers Using High Tunnels in the Central Great Plains of the United States}

\author{
Sharon J.B. Knewtson ${ }^{1}$, Edward E. Carey ${ }^{1,3}$, and M.B. Kirkham ${ }^{2,4}$
}

ADDITIONAL INDEX WORDs. survey, hoophouse, vegetable, flower, organic, protected agriculture

Summary. A survey was conducted of 81 growers managing 185 high tunnels in Missouri, Kansas, Nebraska, and Iowa to collect information about their high tunnel management practices. The survey was administered from 2005 to 2007 using internet-based and written forms. The average respondent had 4 years of high tunnel experience. The oldest tunnel still in use was 15 years old. Twenty-five percent of respondents grew crops in their high tunnels year-round. Tomato (Solanum lycopersicum), lettuce (Lactuca sativa), spinach (Spinacia oleracea), cucumber (Cucumis sativus), pepper (Capsicum spp.), leafy greens, and flowers were the most common crops. Organic soil amendments were used exclusively by $35 \%$ of growers, and in combination with conventional fertilizers by an additional $50 \%$ of growers. The summary of management practices is of interest to growers and the industries and university research and extension scientists who serve them. Growers typically reported satisfaction with their high tunnels. Growers with more than one high tunnel had often added tunnels following the success of crop production in an initial tunnel. Labor for crop maintenance was the main limiting factor reported by growers as preventing expanded high tunnel production.

$\mathrm{H}$ igh tunnels are walk-in plasticfilm-covered structures used to alter the crop environment. Growers use high tunnels for season extension and to enhance crop quality and yield (Lamont, 2005). This increased crop quality and yield are reported in many crops (Lamont, 2005). High tunnel benefits are reported internationally. For example,

This is contribution no. 10-240-J from the Kansas Agricultural Experiment Station.

We thank the growers who, by completing a survey, assisted with ongoing high tunnel research. Thank you also to Candice Shoemaker (Department of Horticulture, Forestry, and Recreation Resources) for reviewing the questionnaire and suggesting format improvements; to high tunnel growers Daniel Nagengast and Tom Circle for reviewing question clarity; to Lewis Jett and Laurie Hodges for assistance in contacting growers; and to John Bauer (Department of Sociology, Geography, and Earth Sciences, University of Nebraska at Kearney) for creating the map. We thank Leigh Murray, Professor, and James J. Higgins, Professor, both in the Department of Statistics at Kansas State University, for discussions regarding the statistical analysis.

This work was supported in part through the USDA's Sustainable Agriculture Research and Education (SARE) graduate student grant to the senior author (project no. GNC05-048, Soil and Crop Quality under High Tunnels).

${ }^{1}$ Department of Horticulture, Forestry, and Recreation Resources, Kansas State University, Manhattan, KS 66506

${ }^{2}$ Department of Agronomy, Kansas State University, Manhattan, KS 66506

${ }^{3}$ Current address: Centro Internacional de la Papa (CIP) c/o CSIR-Crops Research Institute, P.O. Box 3785, Kumasi, Ghana.

${ }^{4}$ Corresponding author. E-mail: mbk@ksu.edu. quality and yield were improved in high tunnel-grown strawberry ( Fragaria $\times$ ananassa) in Croatia (Voca et al., 2006), India (Nevkar et al., 1998), and Kansas (Kadir et al., 2006). High tunnels provide a barrier to wind and rain, and to some extent they may exclude animal and insect pests (Lamont, 2005). Rainfall protection in high tunnels results in reduction of foliar diseases (Orzolek et al., 2004). Winter production in unheated high tunnels may be limited by air temperature in some climates, but increased soil temperature may allow overwintering or early planting. Air temperatures in a high tunnel from late autumn to early spring typically reach minimum daily temperatures only $l$ to $4{ }^{\circ} \mathrm{C}$ higher than adjacent open fields (Akinci et al., 1999; Both et al., 2007; Rader and Karlsson, 2006; Reiss et al., 2004; Waterer and Bantle, 2000), but the minimum soil (upper $10 \mathrm{~cm}$ ) temperature may be 1 to $7^{\circ} \mathrm{C}$ warmer (Both et al., 2007; Rader and Karlsson, 2006; Reiss et al., 2004). The average minimum temperature of strawberry crowns under high tunnels was $5^{\circ} \mathrm{C}$ higher than in adjacent fields from December through February in Kansas (Kadir, et al., 2006). Warmer air temperatures in high tunnels have allowed faster accumulation of growing degree days, which brings high tunnel crops to faster maturity (Both et al., 2007; Waterer and Bantle, 2000). In Kansas, harvest of strawberry overwintered in a high tunnel began 5 weeks before field harvest (Kadir et al., 2006).

Protected agriculture in plastic film structures began in the 1950s (Enoch and Enoch, 1999). Vegetable, flower, and small fruit producers use high tunnels. In Asia and Europe, high tunnel use increased rapidly, especially in Japan, where $93 \mathrm{~km}^{2}$ of vegetable production were reportedly under plastic film by 1970 (Enoch and Enoch, 1999). In 1999, greenhouse or plastic house production was reported to be 800,000 ha worldwide (Enoch and Enoch, 1999). Most of this was under simple plastic houses, with the exception of the glass greenhouses of northern Europe (Enoch and Enoch, 1999). China, Japan, and the Mediterranean region lead in high tunnel crop production (Enoch and Enoch, 1999). High tunnel use continues to expand (Lamont, 2009). Around the Mediterranean, there was a $50 \%$ increase in plastic tunnels between 1985 and 1995 (Baudoin, 1999). It was also during this time that interest in high tunnels surged in the United States. Interest in high tunnel research has spread from the northeastern U.S. (Lamont et al., 2002) to other regions of the United States. In 2007, high tunnels were reported in 45 states, with ongoing research and demonstration projects underway in 36 states (Carey et al., 2009).

\begin{tabular}{llll}
\hline $\begin{array}{l}\text { Units } \\
\text { To convert U.S. to SI, } \\
\text { multiply by }\end{array}$ & U.S. unit & SI unit & $\begin{array}{l}\text { To convert SI to U.S., } \\
\text { multiply by }\end{array}$ \\
\hline 0.4047 & $\mathrm{acre}(\mathrm{s})$ & $\mathrm{ha}$ & 2.4711 \\
0.3048 & $\mathrm{ft}$ & $\mathrm{m}$ & 3.2808 \\
2.54 & inch $(\mathrm{es})$ & $\mathrm{cm}$ & 0.3937 \\
0.4536 & $\mathrm{lb}$ & $\mathrm{kg}$ & 2.2046 \\
48.8243 & $\mathrm{lb} / 1000 \mathrm{ft}^{2}$ & $\mathrm{~kg} \cdot \mathrm{ha}^{-1}$ & 0.0205 \\
1.6093 & mile(s) & $\mathrm{km}$ & 0.6214 \\
2.5900 & $\mathrm{mile}^{2}$ & $\mathrm{~km}^{2}$ & 0.3861 \\
$\left({ }^{\circ} \mathrm{F}-32\right) \div 1.8$ & ${ }^{\circ} \mathrm{F}$ & ${ }^{\circ} \mathrm{C}$ & $\left(1.8 \times{ }^{\circ} \mathrm{C}\right)+32$ \\
& & &
\end{tabular}


The number of growers using high tunnels in the central Great Plains of the Unites States has increased steadily in the past decade. In 2001, university researchers began doing variety and fertility trials in high tunnels in Missouri, and in 2002, they were started in Kansas and Nebraska (E. Carey, L. Hodges, and J. Quinn, personal communication). Interest in high tunnels continues among growers. In recent years, presentations about production in high tunnels have drawn large producer audiences at the Great Plains Vegetable Conference in St. Joseph, $\mathrm{MO}$, held annually in January [attendance: 102 in 2004, 89 in 2005 (year of a bad snowstorm), 109 in 2006, 110 in 2007,108 in 2008,145 in 2009 , and 183 in 2010 (year with a bad snowstorm with several cancellations) (K. Cook, personal communication)]. It would be useful to document current management practices of high tunnel users in this region, which are relatively recent forays into crop production using this new method. The information can be used to match research and extension activities in the central Great Plains of the United States with the interests and needs of clientele growers. Industries that serve growers in the region will be interested in management trends. The information may also be of interest to growers considering the use of high tunnels, or extension personnel in other regions considering priorities in the development of high tunnel research programs.

The objective of this article is to report information about high tunnel use and management practices of growers of horticultural crops in Iowa, Kansas, Missouri, and Nebraska as documented in a paper and online survey. It was the large number of experienced growers who responded to the survey that made this report of significance.

\section{Materials and methods}

A survey of high tunnel growers in Iowa, Kansas, Missouri, and Nebraska was conducted from 2005 through 2007. The target population for the questionnaire was growers who had used high tunnels for inground crop production for more than 2 years. The survey did not include container production under high tunnels.
The questionnaire consisted of 30 multiple choice or fill-in-the-blank questions and six open-ended questions. The questions covered the physical description of tunnels, crop history, nutrient management (including organic matter additions), tillage management, irrigation methods, and grower perceptions. The survey did not cover pest and disease incidence and management or economic profitability.

The questionnaire was offered online and in paper format. The online questionnaire was posted in June 2005 and removed in Oct. 2007 as a link from a website maintained by Kansas State University that specializes in topics of interest to high tunnel users. Twenty-one surveys were collected from this website. Five of these web survey respondents were from the four-state target region and are included in this report. The sixteen respondents from other states were not included in this report.

The questionnaire was offered in booklet format at the Great Plains Vegetable Growers Conference held in St. Joseph, MO, in Jan. 2006. Contact information of vegetable producers possibly using high tunnels was provided by research and extension agents in Iowa, Kansas, Missouri, and Nebraska, and by other growers. The senior author traveled to visit growers who had used high tunnels for more than 2 years in the four-state region. The questionnaire was delivered during the visit, if the grower had not already completed one at the Great Plains Vegetable Growers Conference or online. Growers who did not return the questionnaire during the farm visit were given an addressed and stamped envelope for survey return. Only four growers did not return the questionnaire after a farm visit. Seventy-six questionnaires were collected in booklet format from growers in the four-state region.

Questionnaire responses from the 81 participants from Iowa, Kansas, Missouri, and Nebraska were compiled in spreadsheets in Nov. 2007. Not all participants responded to all questions. Survey questions discussed in this report are presented with response counts in Table 1. Survey question responses presented in the Results section as percentages are based on the number of respondents to a particular question.
During visits to farms, the senior author had informal discussions with many of the growers who participated in the survey presented in this report about crop production in high tunnels. Growers were asked how university research and extension personnel could serve them and also about topics they would find interesting at future workshops or conference events.

Multivariate statistical analysis of survey response data showed no significant results. It was recognized at the beginning of the study, when the survey was written, that a cluster analysis was not appropriate for the data analysis. No attempt was made to determine differences among the four states, because they were contiguous.

\section{Results and discussion}

Eighty-one growers from Missouri, Kansas, Nebraska, and Iowa completed questionnaires. Locations of survey participants in these states are indicated on the map (Fig. 1). States were represented as follows: 54\% Missouri, 23\% Kansas, 14\% Nebraska, and 9\% Iowa.

The oldest high tunnel still in use was built in 1991, in Elm Creek, NE. The median and mode of production experience with high tunnels was 4 years at the time growers completed the survey (Fig. 2). The year 2002 saw the largest number of survey respondents construct an initial high tunnel in a single year. Thirteen percent of the participants had used high tunnels for less than 3 years. Growers with less than 3 years of high tunnel experience are under-represented in this survey because they were not actively sought. Given our effort to identify and survey experienced high tunnel producers in the target region, data reported here provide a comprehensive picture for this objective in the states of Missouri, Kansas, Nebraska, and Iowa.

The growers surveyed managed a total of 185 tunnels. Thirty-seven percent of respondents had one high tunnel, and 35\% had two. The maximum number of tunnels any grower managed was 10 .

A variety of high tunnel widths and lengths were reported. The most common high tunnel size was $30 \times 96$ $\mathrm{ft}$. Only seven high tunnels were more than $100 \mathrm{ft}$ in length. One grower had a 400 -ft-long tunnel.

One of the main advantages of high tunnel use is an extended growing 
Table 1. Questions, response options, and selected grower responses from a 2005-07 survey of high tunnel growers in Missouri, Kansas, Nebraska, and Iowa. Questions for which response options were not provided in the survey are indicated by footnotes. The first six questions apply to all the tunnels a grower operates, and the remaining questions apply to one of the tunnels.

\section{Question}

1) How many high tunnels (hoophouses) do you use?

2) When did you begin production in high tunnels? Month and year. ${ }^{\mathrm{x}}$

3) Which of the following crops have you grown in your high tunnels in the past four years? Select all that apply.

4) If you grow flowers, please list your top five flower crops based on volume produced, with most produced listed first then in decreasing order. ${ }^{\mathrm{x}}$

5 ) What are the approximate dimensions of each of your high tunnels (e.g., $14 \times 20 \mathrm{ft}$ )? If various sizes, indicate all sizes. ${ }^{\mathrm{x}, \mathrm{w}}$

6) Are you experiencing soil quality problems in any of your high tunnels?

For the following questions, consider one of your high tunnels in which you are experiencing soil quality problems. If you do not have soil quality problems, consider the high tunnel that has been in production the longest.

7) Please, indicate the category that applies to your high tunnel.

8) Which of the following crops have you grown in your high tunnel in the past four years? Select all that apply. ${ }^{y}$

9) Do you use only organic amendments?

10) Which of the following organic amendments have you used in the past four years? Select all that apply. ${ }^{y}$

11) How often do you apply organic amendments? Select one best answer.

12) About how much organic amendment do you add on an annual basis? Please indicate the amendment and rate; for example, $400 \mathrm{lb}$ mushroom compost per 1000 square foot, and $50 \mathrm{~kg}$ bone meal per 5 foot $\times 20 \mathrm{ft}$ bed. . $^{\mathrm{x}, \mathrm{w}}$

13) Which fertilizers do you use in your high tunnel? Select all that apply. ${ }^{\mathrm{y}}$

14) How frequently do you till the soil under your high tunnel? Select one best answer.
Soil quality problem (12), Longest production time (59)

Flowers (21), tomatoes (69), peppers (24), cucumber (26), melons (9), beans (22), peas (10), squash (16), onion (10), asparagus $(0)$, spinach $(32)$, lettuce $(32)$, other leafy greens (21), strawberry (14), brambles (1), other (14)

Yes (28), No (51), do not know (0)

Homemade compost (33), commercial compost (20), urban waste compost (1), animal manure (37), worm castings (16), mushroom compost (3), seaweed/kelp (20), fish emulsion (20), bone meal (12), lime (26), gypsum $\left(\mathrm{CaSO}_{4}\right)(18)$, Epsom salt $\left(\mathrm{MgSO}_{4}\right)$ (14), other (21)

Never (8), once each 4 years (2), once each 2 years (10), annually (48), twice a year (7), more frequently $(3)$

Total responses (no.)

81

Commercial multi-element combination (44), commercial slow release fertilizer (8), micronutrient mix (6), urea (3), calcium nitrate $\mathrm{Ca}\left(\mathrm{NO}_{3}\right)_{2}(28)$, potassium nitrate $\mathrm{KNO}_{3}(8)$, sodium nitrate $\mathrm{NaNO}_{3}(0)$, ammonium nitrate $\mathrm{NH}_{4} \mathrm{NO}_{3}(5)$, triple superphosphate (0), lime (21), gypsum $\mathrm{CaSO}_{4}(15)$, Epsom salt $\mathrm{MgSO}_{4}$ (16), other (12)

Never (2), once every two years (3), annually (37), twice a year (25), four times a year (8), more than four times a year (3) 
Question

15) To what depth do you usually till? Select one best answer.

16) How often do you till the subsoil (i.e., with a subsoiler or ground fork)?

17) What type of irrigation do you use? Select the options that best describe your primary method of irrigation.

18) Do you occasionally soak the soil to result in deep leaching?

19) Some high tunnels are designed to be stationary and some to be moveable. How often is this high tunnel moved? Select the one best answer. ${ }^{y}$

20) Is the plastic cover of this high tunnel removed during the year. If so, for how long? Select the one best answer. ${ }^{y}$

21) How often do you irrigate the soil when no crops are being produced in your tunnels? Select the one best answer. ${ }^{y}$

22) During which mo. do you typically have a crop (commercial or cover crop) in your high tunnel? Select all that apply.

23) Do you use a cover crop when commercial crops are not being produced in this high tunnel? Select all that apply.

24) Do you use a crop rotation? If yes, describe briefly. ${ }^{y}$

25) Have you had your high tunnel soil tested for nutritive quality?

26) If you have soil quality problems in your high tunnels compared with open field production, please describe these problems. ${ }^{\mathrm{x}}$

27) Are there any other problems that you've experienced in your tunnels that might be related to soil quality and management? Please describe. ${ }^{x}$

28) If you have had no soil problems in your high tunnel, why do you think that is the case? ${ }^{x}$

29) What factors in your opinion have attributed to the soil quality or crop productivity in your high tunnel? For example: compaction by a bulldozer, alkaline water source, addition of four tons horse manure in the first year of site preparation, excellent soil from the start, etc. ${ }^{x}$

${ }^{2}$ Tomato (Solanum lycopersicum), pepper (Capsicum spp.), cucumber (Cucumis sativus), melons (Cucumis melo and Citrullus lanatus), bean (Phaseolus spp.), pea (purposely ambiguous term that could include Pisum sativum, Vigna unguiculata, Cicer arietinum, etc.), squash (Cucurbita spp.), onion (Allium cepa), asparagus (Asparagus officinalis), spinach (Spinacia oleracea), lettuce (Lactuca sativa), strawberry (Fragaria Xananassa), brambles (Rubus spp. or Ribes spp.)

y Response options partially provided. Respondent fills in blank to provide additional information such as listing "other" crops or amendments.

${ }^{x}$ Response options not provided. Respondent provides answer.

${ }^{\mathrm{w}} \mathrm{l} \mathrm{ft}=0.3048 \mathrm{~m}, 1 \mathrm{lb} / 1000 \mathrm{ft}^{2}=48.8243 \mathrm{~kg} \cdot \mathrm{ha}^{-1}, 1 \mathrm{~kg}=2.2046 \mathrm{lb}, \mathrm{l}$ inch $=2.54 \mathrm{~cm}$.

season for crop production. Growers extended their crop season by planting earlier in the spring and some crops extended into the autumn. On average, high tunnels had a crop for 9 months of the year. January was the least used month, with only $33 \%$ of high tunnels in use (Fig. 3). Twentyfive percent of growers grew a crop or cover crop in their high tunnel year round.

The most common crop in high tunnels was tomato. Ninety-one percent of growers surveyed produced tomato in a high tunnel within the past 4 years (Table 1, Fig. 4). Growers who considered tomato to be their main crop may have used high tunnel space for a different crop in the past 4 years. During visits, the author observed that a bed of shorter plants, like strawberry or leafy greens, was sometimes grown under the curved side edges of quonset-shaped tunnels, while tomato was grown in the higher center. Also, some growers produced crops for personal use when tomato crops were not in the high tunnels.
The majority of growers produced several vegetables in their high tunnels. Salad crops like lettuce, spinach, other leafy greens, cucumber, and pepper were favored for high tunnel production (Fig. 4). Bean (Phaseolus spp.), onion (Allium cepa), broccoli (Brassica oleracea var. italica), eggplant (Solanum melongena var. esculentum), squash (Cucurbita spp.), and melon (Cucumis melo and Citrullus lanatus) were among a medley of crops grown. More vegetables not represented in Fig. 4 were 


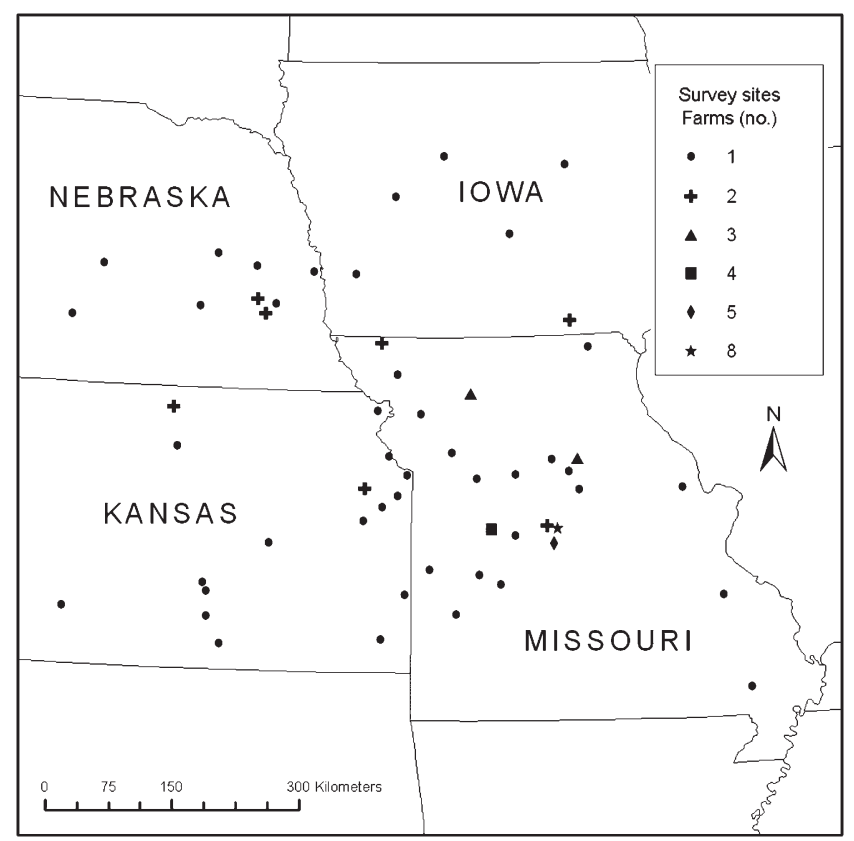

Fig. 1. Locations of 81 high tunnel producers surveyed from Iowa, Kansas, Missouri, and Nebraska. The survey was conducted from 2005 to 2007 $(1 \mathrm{~km}=0.6214$ mile $)$.

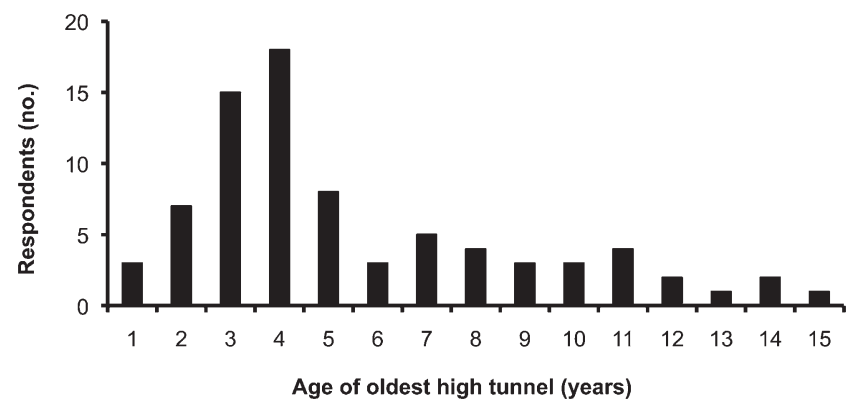

Fig. 2. Years of high tunnel crop production experience reported by producers from Iowa, Kansas, Missouri, and Nebraska $(n=79)$ at the time of completing a survey conducted from 2005 to 2007.

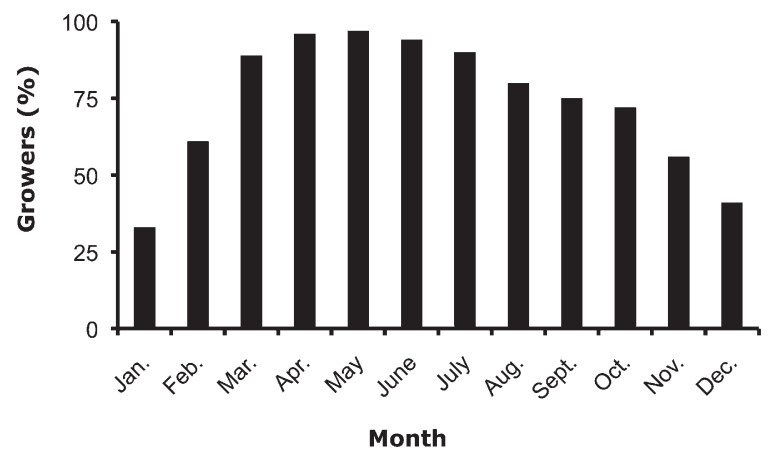

Fig. 3. The number of producers reporting a crop in a high tunnel during each month of the year. Results of a survey of 81 growers from Iowa, Kansas, Missouri, and Nebraska conducted from 2005 to 2007.

grown, but by less than $5 \%$ of those surveyed.

Internationally, the most important high tunnel crop is tomato, followed by pepper, cucumber, muskmelon (C. melo), and then lettuce (Lamont, 2009). In the central Great Plains of the United States,

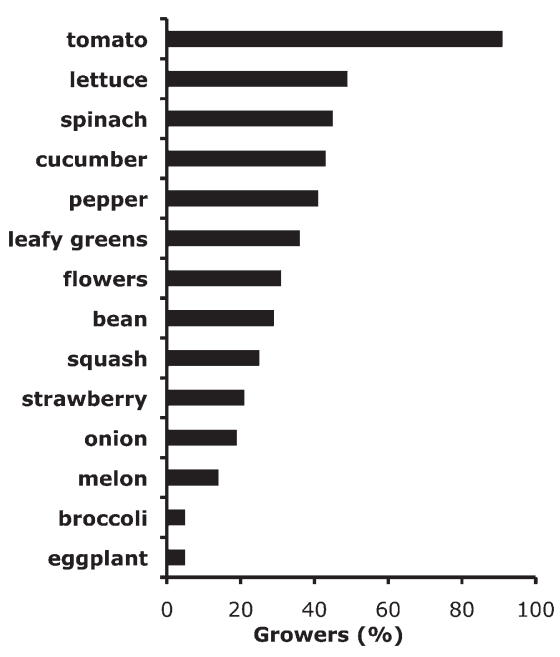

Fig. 4. Proportion of growers that reported producing various crops in high tunnels during the previous 4 years. Results of a survey of $\mathbf{8 1}$ growers from Iowa, Kansas, Missouri, and Nebraska conducted from 2005 to 2007.

salad greens are second only to tomato.

Thirty-one percent of the growers surveyed produced flowers in their high tunnel. Growers collectively listed 43 flower crops that they had grown. Lisianthus (Eustoma grandiflorum) was the most commonly grown flower, reportedly grown by 10 of the 25 respondents who grew flowers. Delphinium (Delphinium nuttallianum), dianthus (Dianthus armeria), geranium (Pelargonium $\times$ domesticum), petunia (Petunia hybrida), sweet pea (Lathyrus odoratus), zinnia (Zinnia elegans), and tulip (Tulipa spp.) cut flowers were grown by four growers. Other flowers were grown by fewer than four growers.

Single crop growers did exist. Tomato was the sole crop for $26 \%$ of growers surveyed. Three percent of growers produced only salad greens, $1 \%$ only flowers, and $1 \%$ only strawberry.

Organic soil amendments were used in high tunnels by $85 \%$ of growers surveyed (this number was determined by looking at the spreadsheets for answers to Questions 9, 10, and 11 in Table 1; note that Question 9 asked if growers used only organic amendments; Question 10 allowed the growers to choose from a list what organic amendments they used; and Question 11 asked how often the amendments were used). Thirty-five percent of the growers surveyed 
reported using organic soil amendments exclusively. Organic additions were made on an annual basis by $62 \%$ of the growers and more frequently by $13 \%$. Animal manure and homemade compost were the most commonly used organic amendments, applied by $54 \%$ and $48 \%$ of growers, respectively. Other organic fertilizers used by growers were seaweed (29\%), commercial compost (29\%), fish emulsion $(29 \%)$, worm castings $(23 \%)$, and bone meal (17\%) (Table 1).

Multi-element conventional fertilizer use was reported by $55 \%$ of the 81 growers surveyed (or $73 \%$ of the 60 growers who responded to questions about use of conventional fertilizers). Incidentally, response to the question about fertilizer use was probably low because growers using only organic amendments were able to skip over it. Calcium nitrate use was reported by $35 \%$ of total survey respondents. Eight growers reported use of slow-release fertilizers. Only six respondents felt the need to apply a fertilizer specifically for micronutrient amendment. Micronutrient deficiency observations were rare, or rather, not severe enough to be visibly noticeable. This may be because location selection favored good soils and organic soil amendments are commonly used.

Calcium and magnesium supplements were commonly used. Gypsum and Epsom salts application were reported by $25 \%$ and $24 \%$ of growers, respectively. Lime application was reported by $39 \%$ of growers. The gypsum, Epsom salts, and lime percentages cannot be calculated directly from Table 1. Respondents could comment on use of these three chemicals in Question 10 or Question 13 or both. The survey was designed to give survey participants freedom in their responses. Their answers were analyzed later to get the percentages presented.

Growers tend to till before planting a new crop; therefore, tillage frequency is mostly determined by crop turnover. Forty-seven percent of respondents reported tilling their high tunnel soil once annually, 32\% twice annually, and 14\% more often than that. Tillage depth was 8 inches or less for $82 \%$ of growers. Annual or more frequent subtilling was reported by $16 \%$ of growers. Drip irrigation was the primary form of irrigation for most respondents. Hand watering was the primary method for $18 \%$. Some growers who use drip irrigation noted that they occasionally use a different irrigation method such as hand watering, sprinklers or misters, and flood irrigation. Fifty-eight percent of growers did not irrigate in the high tunnel when not growing a crop. Fourteen percent irrigated weekly or more often even when not growing a crop. Four percent of growers removed the plastic cover from the tunnel when not growing a crop.

Cover crops had been used by $41 \%$ of growers. Occasional use of cover crops was reported by $21 \%$ of growers. Cover crops were grown on a regular basis in the winter by $13 \%$, in the summer by $2.5 \%$, and in summer and winter by $5 \%$ of growers.

Fifty percent of growers practiced some form of crop rotation. Crop rotation systems were described as growing different crops in successive years or rotating crops to different areas of the high tunnel. Moving the high tunnel to cover a different soil location was part of crop rotation for two growers, and two moved their tunnels at infrequent intervals.

Open-ended questions invited participants to describe possible causes of success or disappointment with crop productivity and soil quality, to compare high tunnel and open field production, or simply to request information of research and extension personnel. Questionnaire information was supplemented with informal discussions with growers during farm visits. Growers showed interest in crop management improvement during discussions and survey responses. Information was requested about research station variety trials and trials with crops that might follow a spring tomato crop. Growers were interested in tomato varieties with good harvest quality and yield, disease resistance, and early harvest. There was also interest in possibilities for autumn tomato production. During farm visits, the senior author was asked about services offered through agriculture extension offices and universities, including how to get soil analyzed for nutrient requirements or tissue samples analyzed to identify disease. Common themes among growers for continued management improvement were disease and pest control, nutrient management, and water management.
Growers in all four states requested information about tomato ripening disorders-especially yellow shoulder and hard core. These disorders were reported in high tunnel and field tomato. They were not an ongoing problem for any grower. They could affect one crop, but not the next, or one grower, but not his neighbor.

High tunnels in this survey were used by hobby horticulturists, growers who supplement income with produce sales, and farmers whose sole income was from produce sales. Growers typically reported satisfaction with their high tunnels. Growers with more than one high tunnel had often added tunnels following the success of crop production in an initial tunnel. Labor for crop maintenance was the main limiting factor verbally reported by growers as preventing expanded high tunnel production on a farm. Growers with more than two tunnels usually spoke of the need to hire labor. The senior author saw many new tunnels, often on neighboring farms. Interest in high tunnel production extends from the pioneering high tunnel growers of the central Great Plains of the United States to other growers and would be growers.

\section{Literature cited}

Akinci, S., I.E. Akinci, A. Karatas, and O. Turkmen. 1999. Temperature changes under different protective structures at the late autumn and early spring periods in Van [Turkey]. Acta Hort. 491:87-91.

Baudoin, W.O. 1999. Protected cultivation in the Mediterranean region. Acta Hort. 486:23-30.

Both, A.J., E. Reiss, J.F. Sudal, K.E. Holmstrom, C.A. Wyenandt, W.L. Kline, and S.A. Garrison. 2007. Evaluation of a manual energy curtain for tomato production in high tunnels. HortTechnology 17:467-472.

Carey, E.E., L. Jett, W.J. Lamont, Jr., T.T. Nennich, M.D. Orzolek, and K.A. Williams. 2009. Horticultural crop production in high tunnels in the United States: A snapshot. HortTechnology 19:37-43.

Enoch, H.Z. and Y. Enoch. 1999. The history and geography of the greenhouse, p. 1-15. In: G. Stanhill and H.Z. Enoch (eds.). Greenhouse ecosystems. Elsevier, Amsterdam, The Netherlands.

Kadir, S., E. Carey, and S. Ennahli. 2006. Influence of high tunnel and field conditions on strawberry growth and development. HortScience 41:329-335. 
Lamont, W.J., Jr. 2005. Plastics: Modifying the microclimate for the production of vegetable crops. HortTechnology 15: $477-481$.

Lamont, W.J., Jr. 2009. Overview of the use of high tunnels worldwide. HortTechnology 19:25-29.

Lamont, W.J., Jr. M.R. McGann, M.D. Orzolek, N. Mbugua, B. Dye, and D. Reese. 2002. Design and construction of the Penn State high tunnel. HortTechnology 12:447-453.

Nevkar, G.S., S.N. Ambad, and U.S. Kadam. 1998. Use of high tunnel poly- house for strawberry in high rainfall zone. J. Maharashtra Agr. Univ. 23: 303-304.

Orzolek, M.D., W.J. Lamont, and L. White. 2004. Promising horticultural crops for production in high tunnels in the mid-Atlantic area of the United States. Acta Hort. 633:453-458.

Rader, H.B. and M.G. Karlsson. 2006. Northern field production of leaf and romaine lettuce using a high tunnel. HortTechnology 16:649-654.

Reiss, E., A.J. Both, S. Garrison, W. Kline, and J. Sudal. 2004. Season extension for tomato production using high tunnels. Acta Hort. 659:153-160.

Voca, S., B. Duralija, J. Druzic, M.S. Babojelic, N. Dobricevic, and Z. Cmelik. 2006. Influence of cultivation systems on physical and chemical composition of strawberry fruits cv. Elsanta. Agriculturae Conspectus Scientificus 71:171-174.

Waterer, D. and J. Bantle. 2000. High tunnel temperature observations. 6 Feb. 2010. <http://www.usask.ca/agriculture/ plantsci/vegetable/resources/veg/ht_ temp.pdf $>$. 